\title{
The Artists Village: Openly Intervening in the Public Spaces of the City of Singapore
}

https://doi.org/10.1515/opphil-2019-0047

Received April 30, 2019; accepted October 28, 2019

\begin{abstract}
This paper focuses on how the social, dialogical and collaborative strategies and practices of The Artists Village openly intervened in the public spaces of Singapore at various times in the city-state's history from 1989 to 2015. The objective of this paper is to draw out how the artists collective used social situations to openly produce relational, participatory and socially engaged art in public spaces with specific functions, history and importance. These various forms of artistic interventions took place on a farm, in shopping malls, on public transport networks and at national monuments during different moments in Singapore's rapid urban transformation. From these examples, one is able to understand why The Artists Village openly intervened in the public spaces of Singapore and how these interventions functioned in their limited scope. Through this study we are able to assess how the varying levels of collaboration, openness and criticality present in their public art projects enabled them to grow outside the centralised system of the nation-state in inserting their practice into the public sphere and engaging the masses.
\end{abstract}

Keywords: openness; collaboration; artistic intervention; public space; public art; site-specificity; relational aesthetics; contemporary art; performance art

\section{Introduction}

Where do we begin our study of public art in the city of Singapore? One less obvious place is The Artists Village and a selection of projects ${ }^{1}$ carried out between 1989 and 2015. Through a study of these public art projects, ${ }^{2}$ we are able to analyse the types of artworks that arose from intervening into public spaces, why they were made and how they functioned as critical artistic interventions despite the limitations faced by the artists' collective. The selection of art projects is presented as a series of outcomes arising from situations of openness and collaborative collectivism ${ }^{3}$ as opposed to art made specifically for the art market, state-sanctioned exhibitions, or public art commissions. A commonality in the projects and artworks selected for this paper is visible in the way the artists' placed themselves in specific public realms to form social interstices in uncommon environments as forms of art that provoke social commentary. In

1 The selection of works is taken from the years 1989, 1991, 2000 and 2015. This selection is made with an awareness that their practice has stretched across three decades and only specific public art projects that relate to Umberto Eco's idea of “The Open Work”, Nicolas Bourriaud's "Relational Aesthetics” and Grant Kester's "Dialogical Art” are included.

2 Throughout the paper, "public art project" will be used to refer to The Artists Village and their artistic interventions into public spaces that are temporal, site-specific and unfolds over time and space. These interventions are termed projects as they involve multiple agencies, artists, arts group or individuals in responding to a specific locale collaboratively.

3 A term used by art historian Reiko Tomii in her suggestion that the foundation of Japanese collective's Gutai group lies primarily on individuals within a collective environment. These 'Anti-Art' art practitioners resisted and pushed art outside of the walls of exhibition halls and institutional sites of art into unconventional locales.

\footnotetext{
*Corresponding author: Adrian Tan, Nanyang Technological University Singapore (NTU), Singapore;

E-mail: pengchai001@e.ntu.edu.sg
}

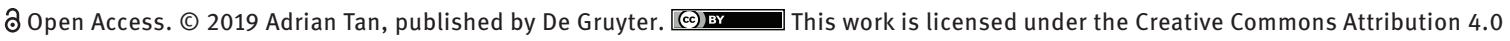
Public License. 
so doing, each specific locale enables the artists' collective to produce durational, open-ended and critical artistic interventions in responding to the function, history and importance of the site.

The Artists Village, arguably the most widely written about Singaporean contemporary art collective by local and regional art historians, was started by artist Tang Da Wu in Sembawang, ${ }^{4}$ a suburban region in the northern reaches of the island-state. ${ }^{5}$ On a decrepit farm set within a soon-to-be razed part of Singapore, the space was to become an important gathering point for an alternative and experimental form of artmaking to take shape. Tang $\mathrm{Da} \mathrm{Wu},{ }^{6}$ who had lived in England for some twenty years, returned to Singapore in the late 1980s and chose to work outside of the urban confines and invited like-minded friends, students and arts practitioners to visit, use the space and stay. He imaginatively expanded the space to allow for an "open, pedagogic process, both for the artist and for his audience"7 as a site for hosting exhibitions and performances from 1988 to 1990.

\section{The Start - the First Open Studio}

The First Open Studio ${ }^{8}$ was an opportunity for individual artists within the artists' collective to collectively present an alternative and experimental art practice in the "site of alterity". ${ }^{9}$ Tang played the role of mentor to other younger artists and displayed his concern and awareness of how the public had been affected by the changes brought about by urban transformation through his art. An element that he frequently emphasises in his practice is the active participation of artist and their viewers, a manner of artmaking that was unconventional for Singapore audiences and artists at that time. In order for this mode of participation and performativity to be effective in his art, his approach was diverse and interdisciplinary and ranged from the use of drawing, painting, installation and performance art, oftentimes incorporating some or all of these elements. To him, being concerned with contemporary social issues and using art as a commentary or a provocation is equal to or more important than their aesthetics. Since returning to Singapore, he has been attuned to the changes around him and this presented a chance for play, experimentation and undefined possibilities in making art collectively, an art steeped in social practice and pedagogical intent that has remained largely consistent in the past thirty years. With large parts of the populace moving to public housing blocks at that time, "the power of the individual when in alliance with the collective would be lost" ${ }^{10}$ according to Tang.

The Artists Village, distinctly sited in a rural setting, proved to be a space where artists embraced conviviality through art conversations, experimental artmaking and a mode of exchange that invariably fostered a spirit of collectivism. Artists started to forge close alliances with one another and communicated openly about art and life in a fluid distribution of energy, power and creative impetus. As shared by artist Koh Nguang How, he observed that in The Artists Village "art and artistic action could exist outside of the market". ${ }^{11}$ For this paper, "The Open Work" ${ }^{12}$ by Umberto Eco is positioned as a suitable framework in

4 61B Lorong Gambas in Sembawang was to become a place where close to forty artists were in residence making art, performing and experimenting with newfound materials.

5 In this paper, Singapore will be referred to as either city, island-state, city-state and country depending on the positioning of the location within the context of the paragraph.

6 For an understanding of Tang's artistic strategies and modes of communication do refer to Wee, "Body and Communication: The ‘Ordinary’ Art of Tang Da Wu.”

7 Wee, “Tang Da Wu and Contemporary Art in Singapore”, 16.

8 The First Open Studio received much press coverage and included works by Tang Da Wu, Hazel McIntosh, Tang Da Hon, Amanda Heng, Baet Yeok Kuan, Lim Poh Teck, Soh Siew Kiat, Vincent Leow, Tang Mun Kit and Wong Shih Yaw, some of which did not continue being part of the collective afterward.

9 This term was used by Seng Yu Jin in his paper "Sites of Alterity: Between the Farm and the Shopping Mall" in the panel that I convened called "From the Rural to the Urban: A Place for The Artists Village in the City" presented in December 2018 at Art and Action: Contemporary Art and Discourse in Southeast Asia, held at LASALLE, Singapore. The conference papers are as yet unpublished. 10 Lenzi, “Concept Context Contestation: Art and the collective in Southeast Asia”, 190.

11 Ibid., 195.

12 To avoid any confusion of terminology, it is important to be specific that the chapter on "Poetics of The Open Work" is referred to in this paper in formulating a dialectic between the work of art and its performer. 
understanding the selected public art projects that were multidisciplinary, discursive and collaborative in nature. In positioning Eco's major treatise as a framework for understanding the art projects, we note that his writings on modern aesthetics ${ }^{13}$ were similarly the result of his early observations of new social and cultural changes in the late 19th and the first half of the 20th centuries. In this paper, we begin from the premise that the shifting role of the viewer is one that responds more openly towards various modern and contemporary forms of art, performances, music and hybrid practices. This characteristic first surfaced and resonated in The Artists Village's First Open Studio, where specific traits of openness ${ }^{14}$ were observed in a never seen before form of "exhibition collectivism"15 in the city.

Unlike being in a gallery or museum, the art object is not privileged over other forms, in fact, the First Open Studio was a collective site for production, interaction, and communication that evolved over time beyond the static and spatial form of an exhibition. "Openness" as proposed by Eco ${ }^{16}$ is an author's arrangement of a sequence of communicative efforts in such a way that the addressee can interpret the original composition as devised by the originator, and yet maintain a level of being "quite literally unfinished" ${ }^{17}$ Koh recounted how wall partitions had been re-used from prior exhibitions in the more formal spaces of the National Museum Art Gallery (NMAG), this Do-It-Yourself (DIY) spirit enabled some works to be hung while other paintings, drawings or sculptures lay in the make-shift studio spaces in various states of being "quite literally unfinished". Artists and their friends constructed these makeshift spaces and planned the open studio show in a self-organised manner. News of the open studio was disseminated through artists and their friends, word of mouth within the art fraternity and neighbourhoods, and various iterations of paper flyers and posters distributed in small batches. Eminent art historian T.K Sabapathy kindled what he saw in the open studio show as "provocative things" 18 that educated the public on new forms of artistic production that provoked them to look at art, three-dimensional forms and exhibition spaces differently. By situating these alternative forms of artistic practice in a rural farm, Seng Yu Jin also wrote:

Most importantly, the public response to this "new" artistic medium ... was encouraging, and this was particularly important given that audience participation is often a crucial part of the whole artistic process. TAV [The Artists Village] was thus able to build not only their reputations but also managed to educate the public to this "new" art form in a relatively short period of time. ${ }^{19}$

Studio spaces doubled as exhibition venue, performance and community space for a new, bewildered and intrigued public who visited the First Open Studio show in large numbers. In a city that had newly ascribed to monolithic concrete institutional settings as a prerequisite for a uni-directional viewing of art, such a DIY, laid-back, dispersed, and unconventional setting broke away from the hierarchical and specific locale of an art gallery or museum. One can surmise that this interstitial space was more accessible than the specificity of an art institution where a new mode of art viewing was introduced in which visitors mingled with arts practitioners instead of being fixated with an object-based experience of art. The spectator is, according to Eco's reference of Baroque works of art, induced to "shift their positions continuously in order to see the work in constantly new aspects as if it were in a state of perpetual transformation". ${ }^{20}$ Through Koh's photographic documentation of the show and his oral accounts we are privy to the atmosphere, social interactions and range of artworks presented that

13 This period was a cultural moment largely identified as opening up to ideas of interaction, participation, and communication between art and its receivers in opposition to passive or singular receptions.

14 To the best of my knowledge, the loose collective of artists commonly referred to as Singapore's first artists' colony had not been influenced by the ideas of Umberto Eco in his treatise on "The Poetics of The Open Work".

15 Another term that art historian Reiko Tomii uses to introduce modern practices of group exhibitions in reaction against art institutions and state-initiated exhibitions.

16 This definition forms the crux of our discussion in this paper, where it cannot be confused with and needs to be understood separately from other more conventional applications of the term "open work".

17 Eco, “The Open Work", 4.

18 See Sabapathy, "Provocative Things", 277.

19 Seng, "Re-visiting the Emergence of The Artists Village", 11.

20 Eco, “The Open Work", 7. 
perpetually transformed the utilitarian farm-space into an experimental abode. Ranging from his observations of Lee Wen's performances to Tang Da Wu's gestural paintings, the show encouraged acts of conscious freedom on the part of the viewer and the artist where the relationship between the artist, the artwork and the audience was fluid and democratic. Similarly, in his written accounts Sabapathy ${ }^{21}$ observed the distinctiveness and importance of this staging of art where The Artists Village is set apart from the uniform practices of other practitioners, as they placed the emphasis of their practice not on the finished work but on "unconditional publicness", being "unreservedly for the public", and most importantly an "all-inclusive site". These observations will be further witnessed in later works that will build on this idea of a social interstice for art production, exhibition and reception. Aligning with notions of collective artmaking, Nicolas Bourriaud's relational aesthetics ${ }^{22}$ is expanded on in later interventions as some of the artists' collective's projects started to place more emphasis on human relations and sociality instead of the objecthood or materiality of the art. This shift towards sociality and relationality in art is observed as they continued making art in uncommon places, pushing their practice into greater visibility and accessibility for public consumption and critique. This took place despite the farm being taken back by the state for redevelopment and the artists' collective becoming space-less. Moreover, through this limitation the artists were emboldened, shifted out into the streets and continued to push viewers out of their familiar boundaries.

\section{The Shift to the Streets - Art Mart}

The island-state of Singapore is a country that writer William Gibson termed the "Disneyland with the Death Penalty"23 in 1993. The use of the term village seemed so out of place ${ }^{24}$ during a period in the country's history where urbanisation was incessant and the perpetual razing of villages and communities making way for ubiquitous ultra-modern shopping malls was unapologetic. After The Artists Village lost their space to urban redevelopment ${ }^{25}$ some artists claimed that the zeitgeist of the artists' colony was no longer there and The Artists Village "died". The unyielding sense of experimentation had enabled artists to mingle, involve other arts practitioners, and invite the public in creating a new "temporary invented community". ${ }^{26}$ During their time at the farm, the rural space created a sense of conviviality, community, and energy in a quickly splintering society segregated by changes in public housing and urban planning. One of the artists' collective's earlier interventions into public space was during Art Mart (1989). Tang Da Wu and members from The Artists Village were invited to be a part of the Singapore Tourist Promotion Board (STB)'s event Art Mart: Singapore International Shopping Festival and given a booth at Cuppage Terrace in the shopping district of Orchard Road. Life Boats was a collaborative public art project that involved artists, musicians, and the audience. The artists took up the act of folding paper boats and invited participants to do likewise. These were lit up at night, with the paper boats placed along borders drawn with chalk, poignantly reminding the passing shopper of the refugee issues in other parts of the region. This poetic gesture took place in the day and resonated throughout the night at the Art Mart event that was part of the larger Shopping Festival in Orchard Road.

\footnotetext{
21 Sabapathy, "Regarding Exhibitions”, 7.
}

22 French curator Nicolas Bourriaud's theory of "Relational aesthetics" included Southeast Asian artist Rirkrit Tiravanija in his reading of artistic practices which focuses on the whole of human relations and their social context, rather than an independent and private space.

23 "Disneyland with the Death Penalty" was William Gibson's first major piece of non-fiction writing. It was first published as the cover story for Wired magazine's September/October 1993 issue.

24 Kwok, "Introduction- Locating and Positioning The Artists Village in Singapore and Beyond", 1. In this introduction, the author states that it is remarkable how The Artists Village had survived and continues to renew its leadership and rejuvenate its collective identity over two decades.

25 Koh mentioned this in an interview with the author. The exact quotation captured in an interview with curator Iola Lenzi in Lenzi, "Concept Context Contestation: Art and the collective in Southeast Asia", 195, is quoted in full below: "The land was acquired by the state from the start and TAV was squatting. There was never a lease. The original farmer who sold the land to the government arranged things with Tang, until it was not possible to stay."

26 See Kwon, "One Place After Another: Site-Specific Art and Locational Identity". 


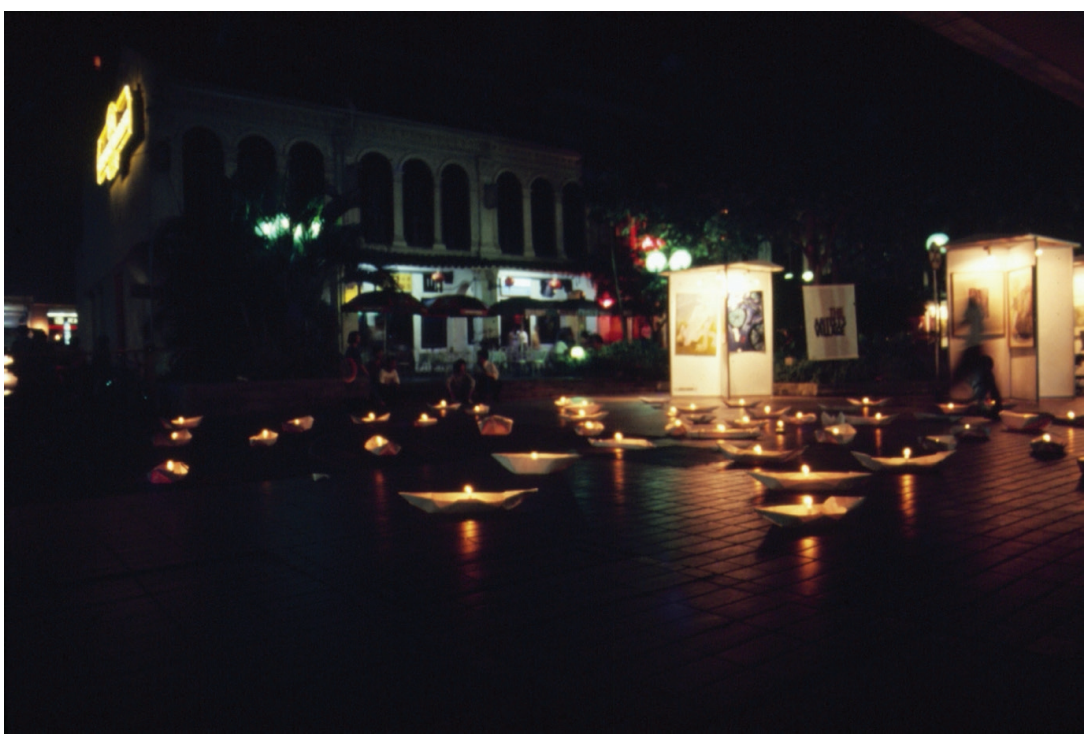

Figure 1: Life Boat: Part of Art Mart: Singapore International Shopping Festival at Cuppage Terrace, in the shopping district of Orchard Road, in 1989. Image Courtesy of Koh Nguang How.

In Miwon Kwon's ${ }^{27}$ concepts of geographical locales and artistic production she considers site-specificity as a precise discomposure between the artwork and its site. Life Boats was set within a construct of a shopping festival and sited in a place of commerce and consumer culture, starkly contrasting the deeply troubling crisis faced by the refugees ${ }^{28}$ in Vietnam against the commercial locale. The involvement of the general public, their oblivion or participation, presented an urgency for site-specificity where the production of a ritual or social gathering to commemorate the crisis is juxtaposed uncomfortably against the consumption of art (objects) in the Art Mart. The example of Life Boats (1989) presents one of the first critical artistic intervention by the artists in and around a shopping mall, where the commentary or provocation of the Indochina refugee crisis is embedded in a noisy procession of songs, quiet participatory work, and poetic lights set within a space of unconditional publicness. The historiography of the artists collective will be explored in other papers, but this work exemplifies the artists' exploration of interfacing with the realities of the city-state, where an urgency to reach out to the general public created a certain measure of discomposure through the participatory art project.

\section{The Body Performed - Four Men in One Suit in the Streets of Singapore}

Upon moving out of the confines of the farm and becoming space-less, the nature of the artistic interventions of Tang shifted to confront new and uncommon locales, intervening in urban spaces of the city, where he approached his projects with varying levels of collaboration, openness and publicness. Four Men in One Suit in the Streets of Singapore (1991) ${ }^{29}$ was an example of an open work sited in various public spaces in the city and performed during "A Sculpture Seminar" co-organised by Tang and The National Museum of Singapore..$^{30}$ Tang presented a collaborative performance artwork, in an attempt to broaden the public's definition and understanding of sculpture, performance art and contemporary art in general. The

27 See Kwon, “One Place After Another: Site-Specific Art and Locational Identity”.

28 Tang was keenly aware of the issues facing Vietnam as there was a Vietnamese refugee camp in Sembawang, Singapore during the 1970s, near to where The Artists Village was situated.

29 Although not entirely performed by members of The Artists Village, this performance art piece maintains similar artistic tropes with the selected art projects presented in this paper.

30 "A Sculpture Seminar" was part of the National Museum of Singapore's programming to introduce the public to art in the expanded field in the lead-up to a key Joseph Beuys exhibition held at the National Museum Art gallery (NMAG). 
performative gesture involved four artists travelling to various locations in the public sphere, encountering bus stops and train stations, loosely co-joined by a blue workman's attire. This performative artwork traversed parts of the city where a series of photographic documentations ensued. This gesture to highlight the everyday social issue of a bus and nascent train system plagued by poor accessibility for handicapped or elderly persons was discursive. The work activated these public spaces to depict a very specific predicament facing the everyday Singaporean, challenging authorities to rethink their modes of urban planning or lack thereof. The performative gesture and its resultant photographic documentation was not an act of activism nor was it a participatory project that involved those in the public realm. It was unlike Life Boats, which was interactive, meditative and open-ended. In one such image, curious members of the public looked on as the artists who shared an oversized blue workman's attire made their way down a flight of stairs heading into the newly opened train station, oblivious to the attention accorded them.

Four Men in One Suit in the Streets of Singapore was a collaborative work akin to Grant Kester's notion of dialogical art $^{31}$ and Eco's open work. This work de-emphasised aesthetics; we encounter a group of artists who designed movement, gestures and a series of awkward and reflexive actions to jolt the alienated viewer into a new awareness and reflexiveness towards one's public spaces. The work can be read as a shifting or mobile public artwork, enabling a social commentary through banality and humour in repositioning this temporal form of site-specific art as a discomposure, despite being limited in their inability to enact any real change to policies or political decision-making. The performance and its subsequent documentation pointed out social issues where the self-deprecating "public artists want(ed) the viewer to move from their familiar boundaries, out of common language and existing representations" 32 to assess their current predicament or social situation. The resultant series of photographic artworks stems from Tang's deep concern with contemporary social issues, where the provocative and playful images produced became open-ended commentaries on issues witnessed in the public sphere.

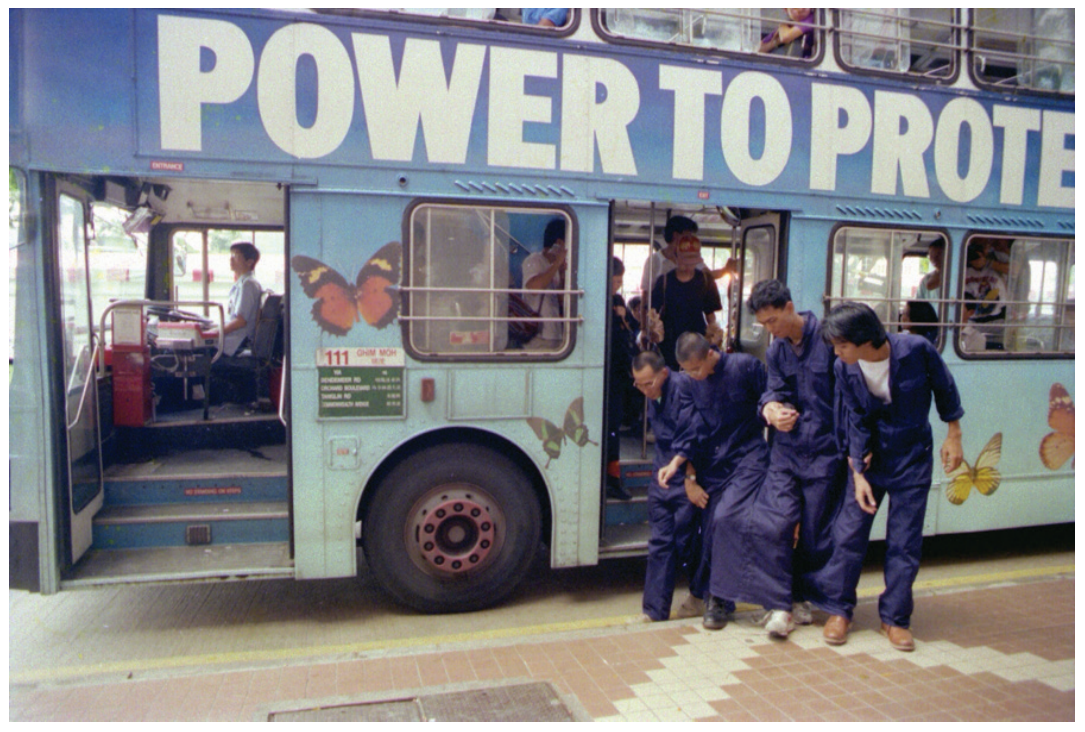

Figure 2: Four Men in One Suit in the Streets of Singapore (1991): Part of A Sculpture Seminar, National Museum Singapore and around the city. Image Courtesy of Koh Nguang How.

Philosopher Jurgen Habermas ${ }^{33}$ theorised that a public sphere is a vital locale that creates social ties, where communities, street culture, architecture and forms of public art contribute to a collective deliberation

31 Kester created a dialogical art framework to analyse and evaluate new socially engaged art practices that are less concerned with aesthetics (or the nature of art) and formal sophistication but more concerned with engaging in real-life collaborations with a community.

32 Art historian, Grant Kester, in his key text "Conversation pieces Community and Communication in Modern Art” taken from 'Conversation Pieces, The Role of Dialogue in Socially Engaged Art' in "Theory in Contemporary Art since 1985”.

33 See Habermas, “The Structural Transformation of the Public”. 
of a city's identity. The Artists Village contributed significantly to Singapore's art history as suggested by writers who have written about their impact on the emergence of alterity in Singapore Art. Throughout its existence, the artists' collective has also been synonymous with prominent contemporary artists who have featured in biennales, triennials and exhibited globally. As an artists' collective, they were more a myriad of artists rather than a homogeneous grouping of like-minded artists working in the same medium or ideology with a clear manifesto. They produced a host of art projects, exhibitions, art gatherings, workshops and events as an evolving grouping of artists. The works from $\mathrm{TAV}^{34}$ remained primarily those of individuals or smaller grouping of artists set within a collective environment, rather than that of a collective entity with similar ideologies, practices or mediums. This differentiation is highly important in the reading of their artistic oeuvre. In the decades that followed the siting of the artists' colony in Sembawang, new modes of artistic practice emerged that built on Tang's philosophy that one (both artist and audience) should look beyond the museum as a space or frame for art, and that art requires an active audience for sharing and learning rather than being kept in museums and appreciated by few. ${ }^{35}$

\section{The Art Bus - Tour De Art Lah!}

A newer grouping of artists who never experienced the conviviality and zeitgeist of the rural scene were motivated to embark on a more collaborative practice that openly intervened outside of the exhibition space into the streets and estates of the city-state. Tour de Art Lah - The Artists Village Show took place as part of the "Singapore Festival of Arts Fringe 1996". For this show, a group of eleven artists came together to transform a public bus into a mobile art exhibition that would ply the streets of Singapore, where the brightly painted bus travelled from schools to new towns and public spaces like bus depots and libraries. Artworks presented in the re-painted and emptied out buses ranged from sculptures, video installations to interactive art pieces that presented opportunities for the public to respond to and discuss these experimental forms of art-making. The art bus, as it was commonly referred to, brought art closer to the public where the individual artists within the collective collaborated with both the state via the newly formed National Arts Council (NAC) ${ }^{36}$ and the private telecommunications company Motorola.

The newer generation of The Artists Village (TAV), some students of Tang and some familiar artists involved in the art event that resulted in a banning of performance art from 1994 to $2003^{37}$ saw their art practice transverse the difficult period, where they started to partake and initiate artworks that engaged public space differently and approached audience reaction more productively. Concurrently, it was during the early 1990s that Nicolas Bourriaud determined that there was a growing form of art that privileged interaction over static forms and opened up a social interstitial space as relational art for social engagement and exchange in opposition to dominant systems and institutional sites of art. It is through this theoretical lens that he highlighted the possible ramifications of privileging social interaction and interpersonal relations as art:

Of course, one fears that these artists may have transformed themselves under the pressure of the market into a kind of merchandising of relations and experience. The question we might raise today is, connecting people, creating interactive, communicative experience: What for? What does the new kind of contact produce? If you forget the "what for?" I'm afraid you're left with simple Nokia art - producing interpersonal relations for their own sake and never addressing their political aspects. ${ }^{38}$

34 The younger members of The Artists Village adopted the acronym "TAV" becoming more contemporary in their positioning as an artists' collective, where members included artists Jeremy Hiah, Kai Lam, Lina Adam, Agnes Kit, Woon Tien Wei, Lee Wen, and Jennifer Teo. The Artists Village and “TAV” will be used interchangeably depending on context to the artists' collective from henceforth.

35 Ideas extracted from an interview by curator and art critic Iola Lenzi with artist Koh Nguang How in her exhibition catalogue "Concept Context Contestation: Art and the collective in Southeast Asia" (2018).

36 In another shift during Singapore's urban development, the National Arts Council (NAC) was put in place in 1991 in an effort to support artists in their practice, exhibitions, education and outreach.

37 In 1994, as part of a New Year's Day performance in Parkway Parade Shopping Mall, artist Josef Ng cut off his pubic hair in public and resulted in a media frenzy. This led to a long ban on governmental funding for performance art. Note: This is documented by Lee Weng Choy in "Chronology of a controversy" (1996).

38 Bourriaud, "Antagonism and Relational Aesthetics", 68. 
The art bus can be considered a conduit that transforms an everyday experience into an art experience that seeks to connect people. With the intention for an art exhibition that is mobile and unreservedly for the public, the artists forged new collaborative methods, a new kind of space to show art and produced a closer interpersonal relationship with the general public. Working with the state had its drawbacks and benefits but more crucially such a collaboration drew attention to how the role of an artist and the audience can be manifold and complicated in our contemporary society despite attempts to connect people and produce communicative experiences. As Bourriaud cautions, one (the artist) should determine what purpose art or specifically relational art serves and determine what political aspect it (the artwork) purports to address. In Tour de Art Lah we see an attempt to connect with the wider audience outside of the art-ecosystem where the use of publicity, spectacle, and state collaboration had vitally enabled greater visibility for The Artists Village. Though questions remained about its reach to the public and its discursive potential as a relational artwork, the dialogue and exchange it generated was transformed during those testing years.

\section{The Artistic Intervention - Artists Investigating Monuments}

Another public art project titled Artists Investigating Monuments (AIM) (2000) ${ }^{39}$ was positioned as an intervention that was "initiated to present contemporary art practices in the public domain and to facilitate connections between art and public audiences". ${ }^{40}$ The artists either collaboratively or individually responded to existing national monuments and local heritage sites in interrogating its historical lineage. Works produced for the project ranged from performance art, installation art, sound art and new media art. AIM presented a series of site-specific open works, where artistic interventions were sited in close proximity to static inanimate objects in crafting "dynamic artistic creation(s)"41 that pointed at socio-political and cultural vexations facing Singapore and the region. The art event was held over one weekend where it professed to engage with post-colonial tropes and touch on varying iterations of nationalism as imagined by the artists. These interventions were carried out through open and dynamic gestures radically juxtaposed upon the stoic forms, some of which were monuments that Singaporeans closely identify with or distantly viewed from afar. Through this, questions were raised about these long-standing monuments, their purpose and value to the people.

Lee $W^{4}{ }^{42}$ erected a prefabricated scaffolding next to a monument at the Raffles Landing Site ${ }^{43}$ and titled it Untitled (Raffles) (2000). He added a performative element to this scaffold, where people could choose to ascend and engage with the monument face-to-face rather than remain rooted in their usual position looking up at the monument. The scaffold engulfed the monument and disrupted the surrounding space, constructing a temporal intervention to a static colossal form. Lee would stand atop the scaffold and invite participants to board the temporary structure to see eye to eye with the founder of Singapore. The work can be read as a commentary or deconstruction of colonialism in Singapore or remain, for the uninitiated, a humorous touristic interjection next to a national monument, oblivious to the critique that was being staged. Lee had wittingly crafted an "image of discontinuity" 44 a term aptly borrowed from Eco, where the monuments existed like stage props in enabling the audience to reassess

39 NAC and the National Heritage Board (NHB) supported the Artists Investigating Monuments (AIM) project in the year 2000, a collaborative attempt by TAV artists to intervene in the public sphere on a large scale. The objective was set out by the artists to critically engage the memories, heritage, history, and currency of the site and its influences.

40 Lingham, “Art Interpreting Heritage (Of Effacements, Pilgrimages, Exhumations \& Effigies)”, 22.

41 Referring to Eco's "The Open Work", he offered a concept of "dynamic artistic creation" that involved the movement from the "closed" to the "open" work, where the artwork is no longer the creation of a static inanimate object, musical movement or piece of writing but full of life, energy and enabling processes of interactivity.

42 Lee Wen is known for his internationally acclaimed "Yellow Man" performances where he paints himself a bright shade of yellow and interacts in various city spaces, critiquing social perceptions and racial biasness.

43 The Raffles Landing Site is where the white poly-marble statue of the founder of Singapore, Sir Stamford Raffles, stands at the mouth of the Singapore River.

44 Eco, “The Open Work”, 17. 
their position and understand the historical value, cultural purpose and political intent of a monument and how it has been carefully integrated into our sensibility.
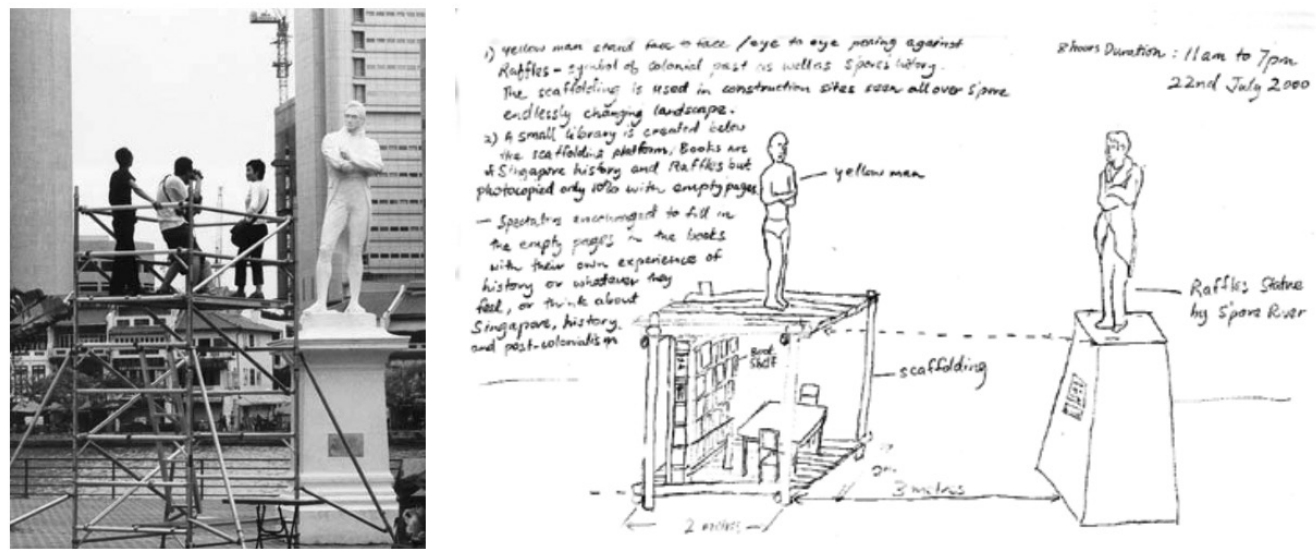

Figure 3: Lee Wen, Untitled (Raffles), 2000: Part of Artists Investigating Monuments. Image taken from Artists Village, The: 20 Years On. Singapore Art Museum. Singapore 2009.

Untitled (Raffles) can be considered a work that is "quite literally unfinished" and required audience participation to complete the work as a co-producer through an actual dialogue. To paraphrase Kester, a dialogical art seeks to replace the "banking" style of art in which the artist deposits an expressive content into a physical object, to be withdrawn later by the viewer, with a process of dialogue and collaboration..$^{45}$ The staging of the performance amongst important public art commissions holds much poignancy in its critical, dialogical and collaborative form. Curator-artist Susie Lingham was one of the visitors to the event and observed:

What was being "negotiated" here? Perhaps that very mutable sense of "national identity", and a certain iconophobia. To locate in order to dislocate in order to relocate: this active interpretation of heritage is an act of deterritorialisation. For those who were witnesses, the fleeting series of performances and installations had subtly affected, if not altered, the ascribed significance and permanence of the monuments. ${ }^{46}$

Untitled (Raffles) framed the public monument in "dislocating in order to locate" how permanent and static forms of public art functions. Lee's piece is open-ended, dialogical with a political configuration, projecting an amalgam of care, reflexivity, and pedagogy through a thought-provoking and openended intervention over a fleeting weekend. What was being negotiated was a co-interrogation and investigation of one's notions of collective memory, personal historical resonance and cultural signification surrounding these specific sites. The motley crew of artists were now initiating and selfcurating contemporary art events (with support from the state) and moving towards a more nuanced mechanism of collaborative collectivism, self-organisation, and institutional awareness in their practice. With this work, TAV has clearly demonstrated an awareness of the significant shifts in how art was being produced regionally and internationally.

In the late 1990s, as mentioned earlier, The Artists Village was driven by a group of younger artists (hence the change to TAV in order to differentiate themselves from their precursors) who never experienced the rural. As a result, the AIM project focused more on site-specific collaborations that unfolded through social interaction, a process of participation and co-production with the public audience. The artists constructed situations where they worked with live events and people as a form of "privileged material forms", ${ }^{47}$ engaging with conversations and dialogues surrounding post-colonial

45 Kester, "Conversation Piece: Community and Conversation in Modern Art”, 10.

46 Lingham, “Art Interpreting Heritage (Of Effacements, Pilgrimages, Exhumations \& Effigies)”, 23.

47 See Finkelpearl, “What We Made: Conversations on Art and Social Cooperation”. 
identity, social conditions, and personal and collective memories. In the case of the AIM projects, they were developed in public spaces around the city, namely publicly familiar sites like the Raffles Landing Site and the former Merlion Park. In the later iterations AIM II and AIM III, the works extended to other sites of monuments like the Kranji War Memorial and memorial sites in Sydney as part of a travelling exhibition curated by the Sydney Museum of Contemporary Art in 2005. These iterations of the performative installations outside of Singapore enhanced The Artists Village's reach to international curators. Their approach became aligned to a convergence of culture and social transformational practices globally despite the market-oriented art world and enabled them to converse, collaborate and re-position themselves in the global art world. Through these examples of interventions into public spaces, AIM and Tour de Art Lah can also be considered forms of "socially cooperative art" 48 that interfaced with the public audience, the public institution and society at large. As membership in TAV continually evolved and individuals or duos formed other art collectives, a self-reflexivity gradually ensued, probably influence by relational or non-art practices situated in the United Kingdom, America, Japan or collectives from the Southeast Asian region.

\section{The Non-Art Event - SRRFM Space}

The Artists Village presented $/{ }^{*} \operatorname{semble}^{*} /{ }^{49}(2015)$ in the old Tanjong Pagar Railway Station, a de-commissioned transportation site that stood as a memory of the railroad connection between Singapore and Malaysia that is now conserved as a national monument and slated to be integrated with future developments on the site or turned into a museum. In 2015, the city celebrated its 50th year of independence. Fanfare and numerous events proceded to take over the city, resulting in art-related exhibitions and events punctuating the nationstate. For the current grouping of TAV artists, this art event was conceived as a site-specific art installation that consisted of photography, video, new media art, and site-specific installations that touched on issues of the city's history, architecture and spatial planning in the lead up to the country's National Day. As the viewer roams around $/{ }^{*}$ semble ${ }^{*} /$, they become autonomous subjects in the artwork SRRFM Space (2015) by Post-Museum. ${ }^{50}$ SRRFM stands for "Singapore Really Really Free Market"51 and is a roving market of wares that are shared freely, and nothing that you see, touch and encounter is for sale. The site-specific "market" is an example of a work that almost removed altogether the shadow and mark of the artist from the artwork, at a time when the city-state's artists were doing the inverse. ${ }^{52}$ As a markedly different experience of art, visitors to Post-Museum's "Free Market" were able to exchange or pick up household items, canvas bags or garments of their choice or contribute an item or service to the temporal "market" enacted by the artists for the public. The installation was visually effervescent with layers of clothes in varying shades of earthy, blacks, greys and coloured hues stacked on the blue tarpaulin canvas. As people walk around and amongst the ware, a vibrancy to the location was created as SRRFM Space became a convivial space of real-life interactivity and openness.

\section{Ibid.}

$49 /{ }^{*}$ semble $^{*}$ was made possible using a National Arts Council grant and presented in the old Tanjong Pagar Railway Station, a de-commissioned transportation site that used to connect Singapore and Malaysia.

50 Post-Museum is run by Woon Tien Wei and Jennifer Teo and a member of The Artists Village and an independent social enterprise that organises and hosts local and international exhibitions.

51 SRRFM is the Singapore chapter of the RRFM. The Really, Really Free Market (RRFM) movement is a non-hierarchical collective of individuals who form a temporary market based on an alternative gift economy. The RRFM movement aims to counteract capitalism in a non-reactionary way. It has a goal to build a community based on sharing resources, caring for one another and improving the collective lives of all.

52 This stems from the fact that in 2015, there were many exhibitions happening in Singapore and none larger than the opening of The National Gallery of Singapore, housing one of the world's largest collection of Southeast Asian art. The state also handed out numerous grants and seed money to museums, artists groups, and cultural institutions to commission events to commemorate fifty years of national independence. 


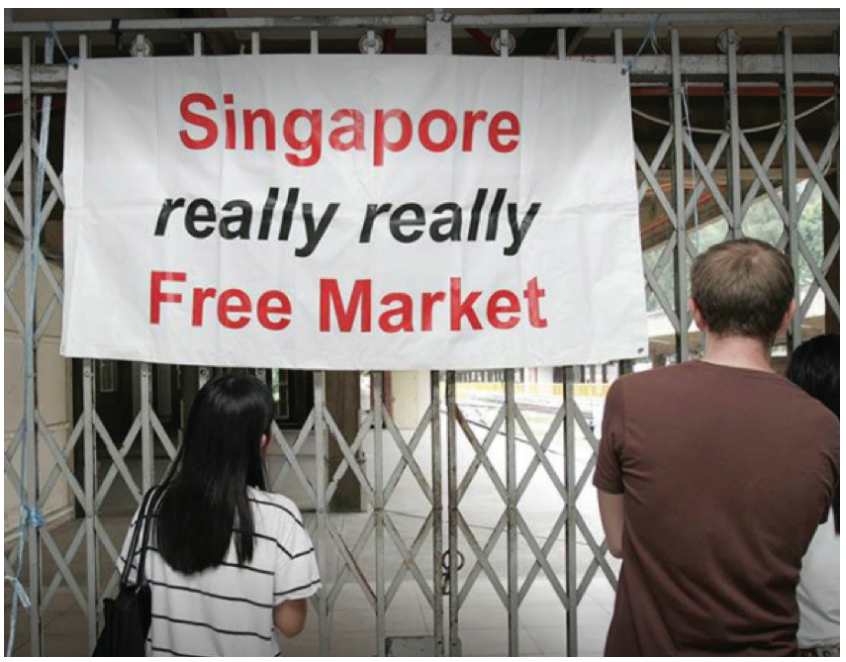

Figure 4: Post-Museum's SRRFM Space at /*semble*/ held at the Former KTM Tanjong Pagar Railway Station in 2015. Image Courtesy of Jason Lee.

This was an art piece borne from the audience experience of the urban physical space where the intervention by the audience was always shifting and in mutable forms as people came and left. The durational artwork blurred the boundary between artist and audience where an informal community was temporally invented or constructed during the weekend of its existence. Post-Museum is an interstice of a social enterprise and an artist-driven non-profit organisation that could be seen as having developed from the tendencies, openness and open-pedagogic approaches by The Artists Village. One could read SRRFM Space as anti-art, non-art or situate the multiple levels of interaction as an intrinsic value and outcome of "socially cooperative art" or "socially engaged art". ${ }^{53}$ Was this a relational, participatory form of art or an installation artwork? Where is the art in this non-hierarchical sharing of gifts based on an alternative gift economy? Were the artists seeking to build a new community based on shared resources in gifting or bonding with its society or community? The idea of gifting or bonding with communities is not new in the art world; Joseph Beuys was an artist widely known to be concerned with democracy in art and how art had to be shared by everyone in society. In his work 7000 Oaks (1982-1987) he planted 7000 trees in Kassel, Germany, over years with the help of volunteers, where each oak was accompanied by a stone of basalt as a gift gesture. Beuys's social sculpture ${ }^{54}$ was invariably an effort on the part of the artist to change the city's social spaces and create an ecological "happening" through a spatial intervention and not an aesthetic object.

We can approach SRRFM Space as an example of efforts by socially engaged artists to enact a real change to the city's social space - an action driven by generosity and set up temporally in an everyday space. The question surrounding whether it is art or an event organised by a social enterprise is precisely a reading that counteracts and reinforces the institutional dependency of works considered as forms of relational art. In reading critically into the work, we speculate that Post-Museum intended SRRFM Space as an attempt to re-configure the position of the artist (in Singapore) in relation to the economic development, social and political institutions in a city largely determined by its institutional structures and hegemony. In further understanding the work, the "market" is on-going and has been re-enacted in various locations in the city from heritage buildings, public art institutions to suburban estates, and has been part of numerous arts festivals and events sanctioned by the state. This rhizomatic nature and duplicity of a socially engaged art installation supported by the state's arts council becomes less concerned with aesthetic innovation and formal art qualities but engages more concretely in collaborations with people outside of the art world, in an effort to extend itself beyond the art audience. Most crucially in demonstrating the shifts in intention

53 Birchall, "Socially engaged art in the 1990s and beyond."

54 Beuys's own terminology that people have come to closely associate him with where "social sculpture" embodies his understanding of art's potential to transform society. 
away from exhibition making, this subtle alteration in the relationship of the author and the audience from one-way communication to a two-way one, implicitly created a new social awareness of the artists within the larger community. SRRFM Space is an embodiment of a work that is unconditionally public where the artwork is unreservedly for and by the public, unhindered by the confines and critique of art.

Art historian Claire Bishop notes that there is "a range of names for the less-authored practice, developing in art that includes socially engaged art, community-based art, experimental communities, dialogic art, participatory, interventionist, collaborative or research-based art" ${ }^{\not 5}$ existing in the art ecology. For understanding works from The Artists Village within Singapore's public spaces, quite a number of these terms have been used or are applicable to the artists from the collective. As illustrated by the examples in this paper, through their openness towards adopting interventions in public spaces as an artistic practice, the artists have increasingly engaged the public in co-navigation and co-negotiation with the city, its spatial arrangement and its power or authority. In so doing, they have wittingly engaged with the spatial politics of Singapore through an art-centred approach that is collaborative, consultative and at the same time dialogical and non-complicit to the state-sanctioned art institutions.

\section{Conclusion}

The urge to read art histories of Southeast Asia has emerged in the past decade or so as the conditions that shaped the perspective of this region gathers momentum with scholars and art historians conducting more in-depth research, interviews and critical discourse about art from this region. This paper forms part of a larger investigation into the diverse perspectives and recurring issues in the politicising and depoliticising of art in these cities. As a study of an artists-initiated practice in Singapore is attempted in this paper, complexities of authority, heritage, differing philosophy, and shadows of colonialism emerged. The artworks and art projects covered in this paper are examples of artists placing themselves in specific public locales, setting up and working with social situations, where they produced critical and at times provocative social commentaries on realities facing the city-state. With this selection of art made in and with the society at various times in the city-state's history between 1989 to 2015, we are able to understand why The Artists Village had placed themselves in public locales ranging from a farm, shopping malls, transportation networks and public monuments to form collaborative public art projects that interfaced with the location and their audience. These interventions in their various iterations had enabled the artists' collective to slip their practice into gaps or spaces of alterity within the porous fabric of the public sphere through gestures of relational, dialogical or socially engaged art. ${ }^{56}$

\section{References}

Birchall, Michael. "Socially engaged art in the 1990s and beyond". http://www.on-curating.org/issue-25-reader/sociallyengaged-art-in-the-1990s-and-beyond.html\#.W2wCeNj-hTY (accessed 21 March 2018).

Bishop, Claire. Artificial Hells: Participatory Art and the Politics of Spectatorship, London: Verso Books, 2012.

Bishop, Claire. “Antagonism and Relational Aesthetics." October, no.110, fall (2004), 51-79.

Bourriaud, Nicolas. Relational Aesthetics. Les Dijon, France: Presses du reel, 2002.

Chen, Patricia. "T.K. Sabapathy on Singapore: The circumstances in which [art] production takes place have not been sufficiently cultivated”. https://patchenlaw.wordpress.com/2013/05/19/video-t-k-sabapathy-on-singapore-the-circumstances-in-which-art-production-takes-place-have-not-been-sufficiently-cultivated-2/ (accessed 17 July 2018).

Chong, Terence (editor). The State and The Arts In Singapore: Policies and Institutions, New Jersey: World Scientific, 2018.

Cvejic, Bojana. “Collectivity? You Mean collaboration?” http://republicart.net/disc/aap/cvejic01_en.htm (accessed 21 March 2018).

Eco, Umberto. The Open Work. MA Cambridge: Harvard University Press, 1989.

55 Bishop, “Artificial Hells: Participatory Art and the Politics of Spectatorship”, 1.

56 The article has been prepared in collaboration with Nanyang Technological University Singapore Centre for Contemporary Art Singapore (NTU CCA Singapore) 
Ewington, Julie. "Five Elements: An Abbreviated Account of Installation Art in South-East Asia." ART AsiaPacific Vol.2 No.1, (1995), 108-15.

Flores, Patrick and Low Sze Wee (editors). Essays on art in Southeast Asia: Charting Thoughts, Singapore: National Gallery Singapore, 2017.

Gibson, William. "Disneyland with the Death Penalty”. https://www.wired.com/1993/04/gibson-2/ (accessed 11 April 2018). Habermas, Jurgen. The Structural Transformation of the Public Sphere - An Inquiry into a Category of Bourgeois Society, Cambridge, MA: MIT Press, 1989.

Ho, Su Fern. "Global Ambitions: Positioning Singapore as a Contemporary Arts Hub." In The State and the Arts in Singapore: Policies and Institutions edited by Chong, Terence, 351-386. New Jersey: World Scientific, 2018.

Kester, Grant. Conversation Piece: Community and Conversation in Modern Art, Berkeley: University of California Press, 2004. Kester, Grant. The One and the Many: Contemporary Collaborative Art in a Global Context, Durham, NC: Duke University Press, 2011.

Koh, Nguang How. “Early Performance Works by Tang Da Wu in Singapore.” Art Journal, vol. 77, no. 4, (2018), 49-61.

Kwok, Kian Woon. "Introduction- Locating and Positioning The Artists Village in Singapore and Beyond." In Artists Village, The: 20 Years On, co-edited by Kwok, Kian Woon and Lee Wen, 1-3. Singapore: Singapore Art Museum, The Artists Village, 2009.

Kwok, Kian Woon and Lee Wen (co-editors). Artists Village, The: 20 Years On, Singapore: Singapore Art Museum, The Artists Village, 2009.

Kwon, M. One Place After Another: Site Specific Art and Locational Identity, Cambridge, MA and London: MIT Press, 2002.

Lacy, Suzanne (editor). Mapping the Terrain: New Genre Public Art. Seattle: Bay Press, 1995.

Langenbach, Ray William. Performing the Singapore state 1988-1995, Ph.D. thesis, Sydney: University of Western Sydney, 2003.

Lee, Wen. Performance Art in Context: A Singaporean Perspective. M.A. thesis, Singapore: LASALLE-SIA College of the Arts, 2006.

Lenzi, Iola. Concept Context Contestation: Art and the collective in Southeast Asia, Bangkok: Bangkok Art and Culture Centre, 2017.

Lingham, Susie. “Art Interpreting Heritage (Of Effacements, Pilgrimages, Exhumations \& Effigies).” In Artists Village, The: 20 Years On, co-edited by Kwok, Kian Woon and Lee Wen, 21-23. Singapore: Singapore Art Museum, The Artists Village, 2009.

Marchart, O. "Art, Space and the Public Sphere(s). Some basic observations on the difficult relation of public art, urbanism and political theory". http://eipcp.net/transversal/0102/marchart/en (accessed 16 June 2018).

Sabapathy, T.K. "Provocative Things", In Writing the Modern: Selected Texts on Art \& Art History in Singapore, Malaysia \& Southeast Asia 1973 - 2015, 277-285. Singapore: Singapore Art Museum, Singapore, 2018.

Sabapathy, T.K. “Regarding Exhibitions.” In Artists Village, The: 20 Years On, co-edited by Kwok, Kian Woon and Lee Wen, 7-10. Singapore: Singapore Art Museum, The Artists Village, 2009.

Say, Jeffery and Seng Yu Jin (editors). Histories, Practices, Interventions: A Reader in Singapore Contemporary Art, Singapore: Institute of Contemporary Art, LASALLE, 2016.

Seng, Yu Jin. "Re-visiting the Emergence of The Artists Village.” In Artists Village, The: 20 Years On, co-edited by Kwok, Kian Woon and Lee Wen, 11-15. Singapore: Singapore Art Museum, The Artists Village, 2009.

Seng, Yu Jin. "The Primacy of Exhibitionary Discourse: Contemporaneity in Southeast Asian Art, 1992 - 2002". http://www. asianarthistories.com/site/the-primacy-of-exhibitionary-discourses-contemporaneity-in-southeast-asian-art-1992-2002/ (accessed 21 March 2018).

Stimson, Blake and Gregory Sholette (editors). Collectivism After Modernism: The Art of Social Imagination After 1945, Minneapolis: University of Minnesota Press, 2007.

Taylor, Nora A and Ly Boreth. (editors.) Modern and Contemporary Southeast Asian Art, Ithaca, New York: Southeast Asia Program Publications, Cornell University, 2012.

Tom Finkelpearl. What We Made: Conversations on Art and Social Cooperation, Durham \& London: Duke University Press, 2013.

Tomii, Reiko. Radicalism in the Wilderness: International Contemporaneity and 1960s Art in Japan, Cambridge, MA: MIT Press, 2016.

Wee, C. J. W. -L. “Body and Communication: The ‘Ordinary’ Art of Tang Da Wu.” In Theatre Research International Vol.42 No.3, (2018), 286-306.

Wee, C. J. W. -L. “Tang Da Wu and Contemporary Art in Singapore.” In Artists Village, The: 20 Years On, co-edited by Kwok, Kian Woon and Lee Wen, 16-20. Singapore: Singapore Art Museum, The Artists Village, 2009.

Yap, June. A Historiographical Aesthetic in Contemporary Singapore and Malaysia, Ph.D. thesis, Singapore: NUS Cultural Studies, 2014. 